\title{
O-405限局性腎細胞癌における腫瘍径の臨床病理 所見に及ぼす影響
}

\section{北里大学 医学部 泌尿器科1)}

石井淳一郎1) 岩村正嗣1) 村本 将倰1) 藤城貴教1)

嶺井定絰1) 平井 祥司 ${ }^{1}$ 宋成浩1) 馬場志郎1)

【目的】限局性腎細胞癌における腫憿径の臨床病理所見に及ほすす 影響について検討した.【対象と方法】1997年腎澏取扱い規約によ $\eta \mathrm{pT} 1-2 \mathrm{NO}(\mathrm{x}) \mathrm{M} 0$ と診断された220症例を対象とした. Follow-up期問 の中央値は52.5ヶ月であった. PT1-T2最大腫㰾径のcutoff值を, 2.5 , $4,7 \mathrm{~cm}$ と便宜的汇設定し, 非再発率, 異型度( grade), 静脈浸潤度

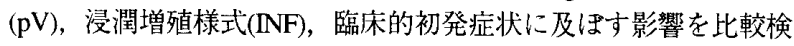
討した.【結 果】 220例中, 再発例は31症例(14.1\%)纪認められた。 腫韵最大径の平均值は7 $6 \mathrm{~cm}$, 再発期間の中央值は 42 ケ月であった。 非再発率ではcutoff值 $4,7 \mathrm{~cm}$ で有意差を認めたが, cutoff值 $2.5 \mathrm{~cm}$ で は有意差は認められなかった，Grade，INFではcutoff值2.5cmのみで 有意差を認めた， $\mathrm{pV}$ ，初発症状の有無では全てのcutoff值で有意差 を認めた、【結論】1999年腎癌取扱い規約の原発腫場進展度におけ るpT1-2のcutoff値 $7 \mathrm{~cm}$ は再発を予測する上で非常に有効であると考 えた. pTla-lb間のcutofftcmの臨床病理学的意義は見出せなかった。 1992年腎癌取扱い規約のpT1である $2.5 \mathrm{~cm}$ 以下の腎癌は、非常に生 物学的悪性度が低く nephron-sparing surgeryの良い適用であると考え た.

\section{腎細胞癌 最大腫瘍径 再発期間}

\section{O-407腎癌を疑い摘除した無症候性腎腫瘍の病理 学的検討}

\begin{abstract}
東京女子医科大学 泌尿器科1)

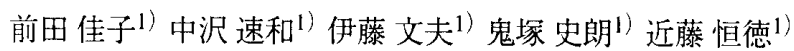
清水朋一1）龍治修1)合谷 (信行1) 東間紘1)

【日的】最近10年間に腎癌と診断し腫崵摘除を行った無症候性腎 腫瘍の病理学的検討を行い, 術前画像診断の精度と腎実質温存手 術の適応について考察する。【対象及び方法】1990 99年に無症状 で発見され，画像検查で腎癌疑いと診断し腎摘除及び腎部分切除 を行った279例を対象とした。対象患者は26 85歳の男190例，女 89例であった。術前画像診断は全例超音波検查と腹部C下検査で行 い, 一部補助診断としてMRI検查が行われた。充実性腫湯249例,

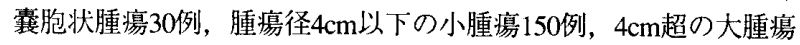
129例であった、【結果】充実性腫湟249例中，良性腫場は腎血管筋 脂肪腫6例，腎オンコサイトーマ4例で，4\%を占めた。相場で は良性腫瘍が9例，7.0\%を占め，督癌の $87.4 \%$ 方腎限局性であった。 一方，大腫晹では良性腫㣀は1例のみで， $40.3 \%$ が局所浸潤癌

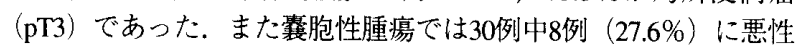
所見を認めず，多房性囊胞との鑑別が困難であった、【結諭】小 さな腎腫瘍において，現在の画像診断では7\%の危険率で腎癌と 良性腫湯の鑑別が困難であった．また $4 \mathrm{~cm}$ 以下の腎癌の大部分は 早期癌であり，小さな腎腫崵は腎実質温存手術を第一選択とする ことが妥当と考えられた。
\end{abstract}

偶発腎腫㵣 腎部分切除術 腎癌

\section{O-406 堅細胞癌の腫瘍径と生存率についての榆討}

\section{新潟泌尿器癌研究グル-プ1)}

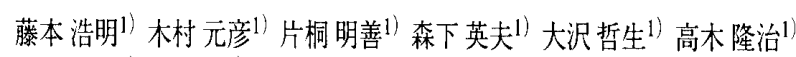

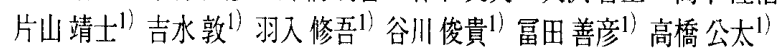

【目的】TNM第 5 版で、腎癌のT1とT2の境界が $2.5 \mathrm{~cm}$ から7 $\mathrm{cm}$ へと 変更された。本邦に扩ける腎癌取扱い規䄪もこれに準じて本年 4 月に改定されたが、これについては様々な意見がある。今回我多 は腎癌における腫瘍径と生存率について検討したので報告する。 【方法】新潟泌尿器癌研究グループ7施設で1988年1月より1999年9 月までに腎摘除術を施行し病理学的に腎細胞癌と診断された症例 で、治療開始時リンパ節転移や遠隔転移を認めない236例を対象

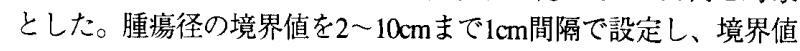
未満とそれ以上の生存率とその相対危除度を比較した。【結果】 腫場径は $1.3 \mathrm{~cm} 20.0 \mathrm{~cm}$ (平均 $5.9 \mathrm{~cm}$ ) であった。 Kaplan-Meier法で有 意な生存率の差が認奶られたのは、境界值 $3 、 4 、 5 、 6 、 7 \mathrm{cmであ}$ った。またCoxの比例ハザードモデルで計算すると、4cm末満の 40 症例 $(5$ 生率 $92.9 \%$ ) に対する4 $\mathrm{cm}$ 以上の166症例 $(5$ 生率 $68.5 \%)$ の 相対危険度が最も高かった(8.696)。【総括】今回我々が行った検討 によれば新規約の7 $\mathrm{cm}$ においても有意差を認めたが、生存率とい う観点からの腫瘍径の境界值は $4 \mathrm{~cm} か ゙$ 最も適当であると考えられ た。

\section{腎細胞癌 腫瘍径 生存率}

\section{O-408堅腫瘍における新規病理組樴分類による臨 床的検討}

\section{岩手医科大学 医学部 泌尿器科}

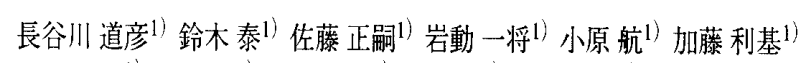

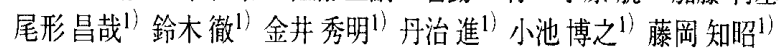

【目的】近年、腎腫瘍の発生母地や分子生物学的因子と関連した 病理組織分類が普及しつつあり、本邦に扔いても1998年WHO分類 に準じて1999年4月に腎癌取扱い規約も改定された。この分類は、 腫韵の生物学的悪性度や予後を反映する因子としての報告があり 従来の組織分類と異なり有用な子後因子であるかを検討した。 【対象と方法】1980年1月から1995年12月までの期間に当科で病理 組織学的に腎細胞癌と診断された183例を対象に第3 版腎癌取扱い 規約に準じた組織分類、UICC腎細胞澏分類と生存率との関係を検 討した。結果】腎癌取扱い規約では、Clear cell 105例(57.3\%), granular 15 例 $(9.8 \%$ ), chromophobe 7 例 $(3.8 \%$ ), spindle 9例 $(4.9 \%)$, Cystassociated 20 例(10.9\%), papillary 12 例(6.5\%), collecting-duct 2 例(1.0\%), oncocytoma 4例(2.1\%)であった。また、UICC分類では、 clear 127例 (81.4\%), chromophilic 10例(8.1\%), chromophobe 7例(3.8\%) とclearの占め る頻度が増加したが、その生存率に有意な差は認めなかった。 5 年生存率の検討においてoncocytoma 100\%, Cyct-associated $90 \%$ と予後 良好でChromophobeは、75.4\% とclearと有意差なく、spindle と collecting-ductは、 $14.3 \% \cdot 0 \%$ でhigh stage, high gradeが多くを占めて いた。さらに他の臨床的予後因子との相関を検討し多変量解析を 加之報告する。

腎腫瘍 病理組織学的分類 生存率 